as will improve the training of radio engineers and secure better recognition of the status of the profession as a wholes The Institution has attempted to improve the education of the young radio technician, not only by the conduct of its own graduateship examinations which continue to attract an increasing number of candidates each year, but also by cooperating with other interested bodies in an attempt to establish suitable national courses of training in the various branches of the telecommunications field. Accounts of the work of the various committees of the Institution during the past year are contained in the report referred to above; and at the twenty-first annual general meeting held on September 25 the Council unanimously recommended the election of Admiral Lord Louis Mountbatten as president of the Institution for the year 1946-47.

\section{Copies of Nature for Service Men in Italy}

Lieut.-Colonel J. C. CASTle wrote a year ago from the firectorate of Disposals in Italy (see Nature, August 4,1945 , p. 140) asking for unwanted copies of $N$ clure to be sent to him for the use of service men sta noned in Italy. There was a good response to this appeal. Colonel Castle now writes that his unit is being disbanded, and no further copies should be forwarded to him ; he asks us to thank, on his behalf and on behalf of the troops who also received these copies of Nature, those anonymous senders who have been forwarding copies of the journal to him.

\section{2) \\ Miffusion in Soltrion}

The Annals the New York Academy of Sciences $(46,209 ; 10 \%$ ) contains six papers by I. G. Longsworth, Ior O. Beckmann, M. M. Bender, E. M. Bevildua, E. B. Bevilacqua, D. M. French, A. R. Goflon, H. H. Harned, L. Onsager, J. L. Rosenberg, and J. W. Williams, dealing with various aspects of the diffusion of electrolytes and macromolecules in solution. The fundamental theory of diffusion and the mathematical treatment of the subject are adequately dealt with, and experimental methods described, references to the literature being given. Attention is directed to these papers, which are likely to interest workers in various fields.

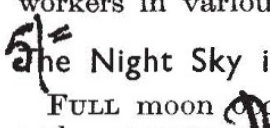

and new mopn of Oct. 24 d. $23 \mathrm{~h} .32 \mathrm{~m}$. The following conjupetio ${ }_{\text {With }}$ the moon take place: Oct. 18d. 131., Satain $4^{\circ}$ S. ; Oct. 26d. 16h., Mars $2^{\circ}$ S. Oct. Wd. $23 \mathrm{~h} .$, Mercury $4^{\circ}$ S. ; Oct. 27 d. 11 h., Venus $7^{\circ}$ In addition to these conjunctions with the moon, the following conjunctions occur: Oet. 10d. 12h., Mercury in conjunction with Jupiter, Mercury $2 \cdot 2^{\circ} \mathrm{S}$. ; Oct. 21 d. 0lh., Mereury in conjunction with Mars, Mercury $2^{\circ} \mathrm{S}$. The following occultations of stars brighter than magnitude 6 take place: Oct. 14d. 0lh. $14 \cdot 0 \mathrm{~m} ., 43$ Taur. $(R)$; Oct. 16 d. $00 \mathrm{~h} .00 \cdot 6 \mathrm{~m}$., 5 Gemi. $(R) ; R$ refers to reappearance and the latitude of Greenwich is assumed. Mercury sets half an hour after the sun on Oct. 1 and is unfavourably placed for observation during the month. The planet attains its greatest eastern elongation on Oct. 31. Venus sets about 25 minutes after the sun on Oct. I and a fow minutes after sunset on Oct. 31. The planet attains its greatest brilliancy on Oct. 13. Mars and Jupiter are unfavourably placed for observation in October. Saturn, in the constellation of Cancer, can be seen in the morning hours, rising at $0 \mathrm{~h} .17 \mathrm{~m}$.,
$23 \mathrm{~h} .27 \mathrm{~m}$. and $22 \mathrm{~h} .28 \mathrm{~m}$. at the beginning, middle and end of the month respectively. The stellar magnitude of Saturn is $\mathbf{0 . 5}$ during October.

It is possible that there will be a short meteor shower on Oct. 10, most likely in the early morning hours, but it may occur before midnight on Oct. 9 . These meteors are the debris of Comet GiacobiniZinner, and the radiant will be in the head of the Dragon. Moonlight will seriously interfere with observations, and it is quite probable that few-and those only the very bright meteors-will be seen.

\section{Announcements}

Prof. M. L. E. Oliphant, Poynting professor of physics in the University of Birmingham, will deliver the thin Rutherford Memorial Lecture of the Physical Sociely on October 7 at 5.15 p.m. in the Royal Institution; he will speak on "Rutherford and the Modern World".

Mr. Geoffrey Heyworth, chairman of Lever Bros. and Unilever, Ltd., and vice-chairman of its sister company, Lever Bros. and Unilever My., has been appointed chairman of the Advisory Council for Sciontific and Industrial Research, in succession to Lord Riverdale, who is retiring after holding the appointment for nine years. Prof. H. W. Melville, professor of chemistry in the University of Aberdeen, has been appointed a member of the Council, in succession to Sir Franklin Sibly.

The Medical Research Council has recently received fr $\mathrm{An}$ Sir Leonard Rogers a further generous addition to the endowment for research in tropical medighe with which he originally entrusted the Corncil in 1926. The capital value of the fund thus created is now approximately $£ 15,000$. The income is applicable to special purposes within the general field of tropical medical research.

PrIor to 1939 the Departments of the History and Philosoph of Science and of the History of Medicine at Uniyersity College, London, which were the only depay ments of their kind in Great Britain, provided either full-time or part-time postgraduate courses of one and two years. On an average they accommodated 30-35 students. With the return of University College to London last year, the study of these subjects has been revived. Prof. H. Dingle is now in charge, and under his supervision courses in the history of science are being provided.

A BRANCH meeting of the Association of Special Libraries and Information Bureaux will be held in the Hornby Library, William Brown Street, Liverpog/ 3 , at 3 p.m. on October 18. Mr. A. B. Agard Evans, of the Ministry of Works, will speak on "Information Service and the Export Trade". Mr. R. Brightman will be in the chair. Particulars can be obtained from Miss L. Wolff (hon. secretary), I.C.I. Ltd., Dyestuffs Division, Hexagon House, Blackley, Manchester 9.

THE following appointments to the post of provincial lirector in the National Agricultural Advisory Seryce have been made: South-East Province, Mr. Eric Rea, at present agricultural adviser to Messrs. R. A. Lister and Co., Dursley ; South-West Province, Mr. Colin D. Ross, at present executive officer to the Devon War Agricultural Executive Committee (in place of Mr. W. T. Price, who has resigned on appointment as principal of Harper Adams Agricultural College). 